\title{
Introduction to the Special Issue: The Status of Black Sociologists in the 21st Century
}

\author{
JeffriAnne Wilder ${ }^{1} \cdot$ Zina T. McGee $^{2} \cdot$ Mamadi Corra $^{3}$ \\ Received: 25 March 2021 / Revised: 27 March 2021 / Accepted: 31 March 2021 / Published online: 23 April 2021 \\ (C) The Author(s), under exclusive licence to Springer Nature Switzerland AG 2021
}

In his seminal work on race and race relations in America, The Souls of Black Folk (1903), noted sociologist and civil rights activist W. E. B. Du Bois proposed that "the problem of the Twentieth Century is the problem of the color-line." That is to say, "the relation of the darker to the lighter races of men in Asia and Africa, in America and the islands of the sea." ([1903] 1994:19). More than 100 years after this proposition, the question of the color line remains one of the most contentious issues in contemporary US society. And while the significance of race for socioeconomic attainment is a classic issue in sociological discourse (see Bonilla-Silva 2003; Borch and Corra 2010; Wilson 1989), until very recently, sociologists have seldom examined the role of race in the academic trajectories of those who claim the discipline itself as a profession. In a recent issue of Social Problems (2017), "Essays on Voices from the Margins: Inequalities in the Sociological House," leading sociological scholars (BonillaSilva 2017; Embrick 2017; Go 2017; Moore 2017; Morris 2017; Romero 2017) challenge sociologists to interrogate the role of race within our own discipline.

This special issue of the Journal of Economics, Race, and Policy (JERP) takes up the challenge of interrogating the role of race in academic/professional sociology by exploring the

JeffriAnne Wilder

jeffrianne@gmail.com

Zina T. McGee

zina.mcgee@hampton.edu

Mamadi Corra

Corram@ecu.edu

1 National Center for Women \& Information Technology, University of Colorado-Boulder, Boulder, CO 80203, USA

2 Department of Sociology, Hampton University, Hampton, VA 23668, USA

3 Department of Sociology, East Carolina University, Greenville, NC 27858, USA status of Blacks among academics and others working in the discipline of sociology. Here, we note that, while the proportion of Black sociologists is still appreciably low, those joining the ranks of professional sociologists continue to grow. In 2001, for example, only 5.8\% of membership in the American Sociological Association (ASA) was reported to be Black. ${ }^{1}$ From 2001 to 2008 , however, that proportion rose to $6.5 \%$, and increased to $8.2 \%$ by 2015 (ASA Membership Database, 2001, 2008, 2015). ${ }^{2}$ It follows that the question of how Black sociologists are faring in our discipline has significant import to the growing number of such sociologists but also to the discipline of sociology more broadly (Bonilla-Silva 2017; Go 2017; Morris 2017).

The three articles in this special issue examine the professional trajectories of Black sociologists, highlighting key challenges and strategies for mitigating them. The papers were submitted to the Journal of Economics, Race, and Policy (with no prior guarantee of publication), went through the regular peer review process, and were revised in response to comments by anonymous reviewers.

The article by Sandra Barnes, "Black Sociologists and Civic Engagement," examines an issue that arguably dates to the inception of our discipline: community-engagement/social activism as an important aspect of the scholarly enterprise. Using quantitative data to examine the time and money donated weekly by 146 Black sociologists, Barnes' article explores correlates of the extent of such donations by these sociologists. The author finds a variety of predictors to the amount of time and money contributed toward civic engagement by Black Sociologists, including (1) attitudinal variables about civic mindedness; (2) excitement about the efforts of civic organizations in which Black sociologists are most

\footnotetext{
${ }^{1}$ In 2001, the proportion indicating "Other" was about 3.0. This proportion rose to 3.8 by 2008 but then declined slightly to about 3.3 by 2015 .

${ }^{2}$ This ASA data source also reported that race/ethnicity status was not reported by $16 \%$ of members in 2001 ; by $5 \%$ of members in 2008 ; and by $14 \%$ of members in 2015. Moreover, it is also noted that data was not reported for members whose race/ethnicity is Native American, American Indian, and Alaskan Native, due to smaller cell sizes.
} 
active; and (3) the breadth of social services offered by those organizations.

In "The Leak in the Academic Pipeline: on Black Women Sociologists," Dari Green and Melinda Jackson-Jefferson, the authors explore the multitude of "structures of oppression" that act as barriers to the incorporation of Black women sociologists in academia. They cite a variety of barriers, including the role of academic "gatekeepers," access to and quality of mentoring from colleagues, and salary differentials. They offer several strategies for developing spaces of equity that might help mitigate barriers faced by Black women sociologists.

Finally, Jasmine L. Harris' article, "Black on Black: the Vilification of "Me-Search," Tenure, and the Economic Position of Black Sociologists," offers a conceptual framework for understanding the "traditional" (White) approach to sociology that inevitably lead to the lower likelihood of Black sociologists than their white counterparts to get published in discipline-specific peer-reviewed journals, hold tenured or tenure-track positions at predominately white institutions, and be awarded tenure.

The co-editors offer special thanks to the authors for making their contributions available to JERP. We are confident that the contributions featured in this special issue will add to our collective understanding of the status of Black sociologists in professional sociology today. We hope that the many suggestions that our esteemed authors offer would be useful to all, but especially Black sociologists who must navigate the multitude of issues that the authors identify. The co-editors extend a special thanks to the external referees of each contribution. Last but not least, we are especially grateful (and extend our sincere thanks) to Gary A. Hoover, the editor of the Journal of
Economics, Race, and Policy, for the opportunity to edit this special issue.

\section{References}

Aldon Morris. 2017. The Scholar Denied: W.E.B. DuBois and the Birth of Modern Sociology. University of California Press.

Bonilla-Silva E. Racism without racists: color-blind racism and the persistence of racial inequality in the United States. Oxford: Rowman \& Littlefield Publishers, Inc.; 2003.

Bonilla-Silva E. What we were, what we are, and what we should b: the racial problem of American sociology. Soc Probl. 2017;64(2):179 87.

Borch C, Corra M. Differences in earnings among black and non-black african immigrants in the United States, 1980-2000: a crosssectional and temporal analysis. Sociol Perspect. 2010;53(4):57392.

Du Bois WEB. 2007. The Souls of Black Folks: Filiquarian Publishing, LLC; 1903.

Embrick DG. Discontents within the discipline: sociological hypnagogia, negligence, and denial. Soc Probl. 2017;64(2):188-93.

Go J. Decolonizing sociology: epistemic inequality and sociological thought. Soc Probl. 2017;64(2):194-1999.

Moore MR. Women of color in the academy: navigating multiple intersections and multiple hierarchies. Soc Probl. 2017;64(2):200-5.

Romero M. Reflections on 'the department is very male, very white, very old, and very conservative: the functioning of the hidden curriculum in graduate sociology departments. Soc Probl. 2017;64(2):212-8.

Wilson WJ. The declining significance of race: revisited but not revised. In: Willie C, editor. Caste and Class Controversy on Race and Poverty. Dix Hills: General Hall, Inc.; 1989. p. 22-36.

Publisher's Note Springer Nature remains neutral with regard to jurisdictional claims in published maps and institutional affiliations. 